\title{
KUESIONER KEPUASAN MAHASISWA TERHADAP PELAYANAN SISTEM Pen+ (Penilaian plus) PADA PERGURUAN TINGGI RAHARJA
}

\author{
Qurotul Aini ${ }^{1}$ \\ Yulianto ${ }^{2}$ \\ Meisa Erawati ${ }^{3}$ \\ ${ }^{I}$ Dosen STMIK Raharja \\ ${ }^{2,3}$ Mahasiswa STMIK Raharja \\ Jl. Jendral Sudirman No. 40, Modernland, Tangerang \\ Email:aini@raharja.info,yulianto@raharja.info,meisa.erawati@raharja.info.
}

\begin{abstract}
ABSTRAK
Penggunaan teknologi internet dalam pembelajaran harus diterapkan sebagai salah satu inovasi baru dalam pemanfaatan media penilaian. Karena dengan adanya Sistem PEN+ ini dapat meringankan pekerjaan Dosen dan Dosen menginput nilai dengan secara Online dengan tepat waktu dan Mahasiswa tidak lagi menunggu lama untuk mendapatkan hasil Nilai UTS, UAS nya. Berbagai jenis sistem dan fasilitas yang tersedia di internet dapat terintegrasi untuk meningkatkan kualitas pada kampus. Perguruan Tinggi Raharja sebagai lembaga pendidikan khusus dalam bidang komputer, telah secara komprehensif menerapkan model penilaian Online. Dalam hal ini kuisioner sebagai salah satu instrumen penelitian ilmiah banyak dipakai pada penelitian sosial, misalnya misalnya penelitian di bidang sumber daya manusia. Di sisi lain perlu upaya tertentu dalam rangka memberikan pemahaman kepada responden sehingga responden ingin menjawab dan menyelesaikan kuesioner. Oleh karena itu kebutuhan sistem yang seperti ini mampu untuk mewujudkan efisiensi dan efektivitas dalam penyediaan fasilitas informasi. Maka dengan metode penilaian online ini yang bertujuan untuk meningkatkan kualitas yang sangat mutu pada Perguruan Tinggi Raharja.
\end{abstract}

Kata kunci: Pen+ “Wah Gampang Kan”, Penplus, Penilaian Online, Penilaian Plus

\begin{abstract}
The use of Internet technology in learning should be applied as one of the new innovations in the use of media ratings. Because with the PEN + system can ease the work Lecturer and Lecturer input value to Online timely and students no longer wait for long to get the value of UTS, UAS her. Different types of systems and facilities which are available on the internet can be integrated to improve the quality of the campus. Higher Education Prog as special educational institutions in the field of computers, has been comprehensively implement assessment models Online. In this case the questionnaire as an instrument of scientific research is widely used in social studies, for example, for instance research in the field of human resources. On the other hand need specific measures in order to provide an understanding to the respondents so that the respondent wanted to answer and complete the questionnaire. Therefore, it needs such a system is able to achieve efficiency and effectiveness in the provision of information. So with this online assessment methods that aim to improve the quality of that very quality in Higher Education Prog.
\end{abstract}

Keywords: Pen + "Easy Wah Kan", Penplus, Online Assessment, Assessment Plus 


\section{PENDAHULUAN}

Perkembangan akan kemajuan teknologi informasi yang sangat pesat dari tahun ke tahun menuntut kita untuk selalu melangkah lebih maju dan mengikuti perkembangan tersebut. Kita dituntut untuk selalu berinovasi dalam menghadapi kemajuan yang semakin pesat saat ini. Manfaat teknologi informasi bagi kehidupan manusia dalam perkembangan yang memiliki peran penting bagi kehidupan manusia. Informasi yang lengkap akan memberikan kepastian dan menghindarkan keraguan akan informasi tersebut. Perguruan Tinggi Raharja sebagai salah satu Perguruan Tinggi yang bergerak di bidang komputer yang selalu berinovasi untuk meningkatkan kualitas. Salah satunya adalah PEN+ (Penilaian plus) telah menerapkan sistem penilaian online.

Sistem sebelumnya penilaian di Perguruan Tinggi Raharja masih sangat manual, berkasberkas nilai pada pihak RPU masih menumpuk dan keterlambatan Dosen dalam penginputan nilai juga masih sangat lama, maka dari itu Mahasiswa masih sangat lama menunggu nilai UTS,UAS dan Mahasiswa masih sangat menunggu nilai sebelum ada sistem Pen+ selama 2 bulan. Dengan adanya sistem Pen+ Mahasiswa dapat melihat nilainya secara mandiri dan mendapatkan email Notifikasi pada Rinfo masing-masing.

PEN+ (Penilaian Plus) merupakan sebuah forum aplikasi Yii Framework, Yii Framework merupakan PHP berbasis- komponen, kinerja tinggi untuk pengembangan aplikasi Web berskalabesar. Nama "Yii" merupakan singkatan dari Yes It Is, untuk menjalankan aplikasi web berbasis Yii anda memerlukan server Web yang mendukung PHP 5.1.0 perkembangan forum ini tidk terlepas dari pengaruh perkembangan zaman. Kemajuan teknologi bukan menuntut forum dikemas secara lebih efisien dan mudah dibawah ini terdapat logo dari Yii Framework II.

Proses penilaian adalah suatu aktivitas dalam sistem pendidikan ini, proses penilaian ini merupakan penglihatan objektif maupun subjektif yang dilakukan terhadap mahasiswa serta dipengaruhi oleh hubungan yang ada dalam proses tersebut. Tentunya proses penilaian juga menuntut adanya penyesuaian atau mengikuti sistem Manajemen Mutu ISO 9001:2008 dalam penggunaan metode proses Penilaian. Adanya realita tersebut Perguruan Tinggi Raharja yang menerapkan konsep IT dalam proses penilaian.

Namun dalam perjalanannya sistem tersebut memerlukan pengembangan dan perbaikan dikarenakan banyaknya permasalahan yang muncul karena keterlambatan nilai yang diharapkan lebih cepat dapat diakses secara luas oleh Pribadi Raharja. Penilaian Plus atau yang sering disebut dengan PEN+ (Penilaian Plus) saat ini telah dilakukan pengembangan sistem penilaian menjadi sistem penilaian online oleh tim PEN+ (Penilaian Plus), PEN+ (Penilaian Plus) telah melalui tahap uji coba yang telah dilaksanakan sesuai dengan tahapan uji coba PEN+ (Penilaian Plus) oleh Tim PEN+ (Penilaian Plus) yang telah dibentuk oleh Manajemen perguruan Tinggi Raharja melalui SK Direktur Perguruan Tinggi Raharja Nomor : 602/SK-PANSUS/PT/V/2016 Tentang Susunan PANITIA KHUSUS (PANSUS) PELAKSANAAN UJI COBA PEN+ (PENILAIAN PLUS) DILINGKUNGAN PERGURUAN TINGGI RAHARJA dan berhasil diimplementasi di Perguruan Tinggi Raharja pada 180 kelas dengan 41 Dosen . 


\section{PERMASALAHAN}

Pada saat ini Perguruan Tinggi Raharia memiliki tempat khusus untuk menyimpan seluruh kegiatan maupun dokumentasi yang telah diselenggarakan, dan Perguruan Tinggi Raharja yang telah membuat sistem yang sangat Efektif yaitu PEN+ (Penilaian Plus) untuk memudahkan dosen dalam mengoreksi nilai nya secara online dan melakukan penginputan nilai nya $\mathrm{H}+3$ yaitu 3 hari setelah dilaksananakannya UTS dan UAS.

Namun, karena masih belum maksimal dan masih kurang efektif menjadikan pihak RPU memakan waktu yang sangat lama. Sehingga dapat didefinisikan permasalahan yang dihadapi saat ini, yaitu permasalahan pertama dapat dikatakan masih belum optimal, hal tersebut dikarenakan pendataan yang masih manual, permasalahan kedua yaitu tidak menyeluruh (tidak update), permasalahan ketiga yaitu menyebabkan mahasiswa untuk menunggu proses nilai nya yang sangat lama sehingga banyak mahasiswa dan mahasiswi yang menunggu lama untuk mengetahui nilainya. Tentunya, dari kedua permasalahan diatas, dapat dirumuskan secara detail menurut penjabaran perkategorinya.

Kronisnya permasalahan tersebut, Mahasiswa masih menunggu nilainya dengan lama dan maish menunggu selama kurang lebih 2 bulan nilai terupdate dialam SIS+ dan dengan hadirnya sistem yang baru ini dapat membantu mahasiswa melihat nlainya secara Online. Setelah Dosen melakukan penginputan nilai kedalam PEN+ . Hal ini dapat sedikit mengurangi keterlambatan waktu untuk penilaian, karena Dosen dapat langsung melakukan penginputan nilai secara online dengan menggunakan jaringan apapun. Hal ini tentu sangat membantu menyelesaikan masalah keterlambatan waktu pengumpulan nilai, sehingga Mahasiswa tidak terlambat untuk mengetahui nilainya kembali .

Mahasiswa masih sangat lama menunggu nilai semesternya yang dikarenakan keterlambatan Dosen sendiri yang terdapat banyak berkas-berkas dari kelas dan matakuliah lainnya. Hampir 3 bulan Mahasiswa mengecek nilai melalui SIS+ Lalu search KHS tetapi terkadang nilai yang muncul masih tampilan nilai semester lalu, maka dari ini PEN+ (Penilaian Plus) membantu Dosen, meringankan Dosen, dan memberikan pelayanan yang terbaik terhadap Para Pribadi Raharja.

PEN+ (Penilaian Plus) ini dapat berguna bagi seluruh civitas Akademik terutama dengan Dosen dosen Perguruan Tinggi Raharja yaitu keuntungan pertama tidak lagi bersifat manual dalam artian bisa diakses secara online secara device. Keuntungan kedua, informasi yang ditampilkan secara menyeluruh. Keuntungan ketiga, Mahasiswa tidak menunggu lama dan mengetahui nilai UTS, dan UAS nya. Dan dibawah ini ada sebuah gambar Sistem penilaiannya yang masih manual yaitu : 


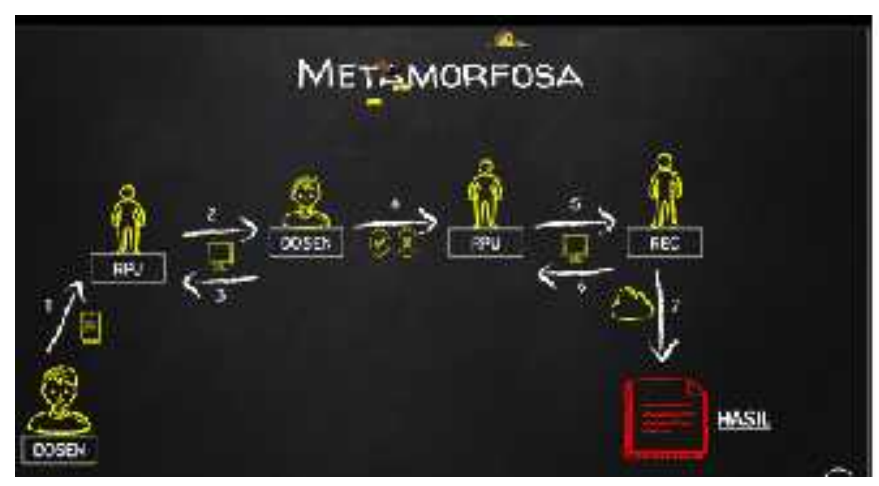

\section{Gambar 1 . Gambar Sistem Penilaian Yang Terkomputerisasi}

Dari gambar diatas adalah gambar sistem penilaian yang terkomputerisasi namun masih belum online, PEN+ (Penilaian Plus) hadir untuk meringankan aktivitas Dosen untuk melakukan penginputan nilai secara online. Dan PEN+ (Penilaian Plus) ini terdapat Kuisioner untuk Mahasiswa agar PEN+ bisa menjadi lebih baik lagi dan mengetahui apa kekurangannya dari sistem PEN+ ini. Maka dari ini PEN+ (Penilaian Plus) membuat Kuisioner Untuk Mahasiswa agar Mahasiswa bisa merasakan Sangat Puas, Puas, Cukup Puas, atau Tidak Puas? Maka dari ini dengan adanya sistem PEN+ dapat Memuaskan mahasiswa agar tidak ada kendala lagi dan menunggu waktu yang sangat lama untuk mengetahui nilai UTS dan UAS Mahasiswa nya. Dari gambar diatas ada satu permasalahan yang di ambil :

Apakah sistem PEN+ sudah berjalan dengan efektif?

Permasalahan ini masih mengecewakan banyak Mahasiswa karena keterlambatan sistem kampus yang masih kurang terupdate. Dengan adanya Sistem PEN+ (Penilaian Plus) ini Dosen tidak lagi datang kekampus untuk membawa berkas-berkas kepada RPU, karena PEN+ (Penilaian Plus) dapat diakses secara Online bisa dilakukan dimana saja Dosen berada diluar kampus.

\section{LITERATURE REVIEW}

Banyak penelitian yang sebelumnya dilakukan mengenai Literature Review. Dalam upaya pengembangan Sistem Penilaian pada Perguruan Tinggi Raharja ini perlu dilakukan studi pustaka sebagai salah satu dari penerapan metode penelitian yang akan dilakukan. Diantaranya adalah mengidentifikasikan kesenjangan (identify gaps), menghindari pembuatan ulang (reinventing the wheel), mengidentifikasikan metode yang pernah dilakukan, meneruskan penelitian sebelumnya, serta mengetahui orang lain yang spesialisasi dan area penelitiannya sama dibidang ini. Beberapa Literature review tersebut adalah sebagai berikut :

1. Penelitian ini dilakukan oleh Erlita Rasdiana pada tahun 2013 dengan judul "Analisa pengembangan sistem System Information Student (SIS) pada Perguruan Tinggi Raharja" Penelitian ini membahas tentang System Informatiom Student (SIS) pada Perguruan Tinggi Raharja, SIS yang berjalan pada saat ini sudah cukup baik, namun sejalan dengan kemajuan dan perkembangan teknologi serta pengembangan dan kebutuhan Pribadi Raharja pada umumnya atas informasi mengenai segala bentuk pemberttahuan dan pengumuman secara umum maupun khusus, kedisiplinan, dan layanan kepada mahasiswa, maka sistem ini memerlukan sistem yang benar-benar handal 
dan dapat berfungsi semaksimal mungkin untuk memberikan informasi serta memenuhi kebutuhan tersebut.

2. Penelitian ini dilakukan oleh Susy Kusuma Wardani pada tahun 2013 dengan judul "Sistem Informasi Pengolahan Data Nilai siswa berbasis Web pada Sekolah Menengah Atas (SMA) Muhammadiyah pacitan". Penelitian ini bertujuan untuk membangun suatu sistem informasi, mempermudah pengecekan, pencatatan dan laporan data nilai siswa yang terkomputerisasi. Aplikasi ini menggunakan multi user ang terdiri admin pada bagian login saat akan membuka aplikasi sehingga keamanan program ada. Sistem ini bekerja memasukan dan menyimpan data laporan nilai dan ensi serta menampilkan info dari sekolah tersebut sehingga lebih mudah mengetahui informasi yang akan disampaikan oleh piha sekolah. Penelitian ini telah mengasilkan sebuah sistem pengolahan nilai yang membantu kerja dari para guru dan wali kelas dan dapat mempermudah pengguna untuk melakukan proses pengolahan nilai agar pengolahan nilai dapat diolah secara efektif dan efisien, sehingga bisa langsung diakses serta informasi (pengumuman) dapat disampaikan lebih baik.

3. Penelitian ini dilakukan oleh Rahmawati pada tahun 2012 yang berjudul "Analisa Penerapan Sistem Informasi Akademik (SIAKAD) Online di Universitas Sultan Ageng Tirtayasa". Penelitian ini dilakukan bukan hanya untuk mengukur kepuasan responden atas penerapan SIAKAD Online selama ini di UNTIRTA menurut mahasiswa dan juga dosen. Menurut Mahasiswa portal Akademik atau SIAKAD Online sudah membantu mahasiswa untuk bisa melihat nilai matakuliah dari tempat tinggalnya tanpa harus datang kekampus. Disamping itu pula, SIAKAD Online sudah memudahkan Dosen untuk dapat menginput nilai dimana saja tidak harus datang kekampus.

4. Penelitian ini dilakukan oleh Untung Rahardja, Muhamad Yusup dan Eva Rosyifa dari Perguruan Tinggi Raharja tahun 2012 yang berjudul "Perancangan Aplikasi iLearning Majalah Online Dengan Menggunakan iOS Programming Pada Perguruan Tinggi”. Penelitian ini membahas sifat publikasi penyampaian informasi bersifat penting karena dapat membantu dan melakukan pencarian akan informasi yang sebelumnya tidak diketahui. Serta media publikasi masih berkaitan satu sama lain sehingga kebutuhan akan informasi sifatnya masih sangat tinggi dan dari sebagian tempat sifatnya masih sangat rendah dan proses pengupdatean akan informasi masih bersifat minim. Sehingga diharuskan melakukan perancangan aplikasi iLearning majalah online dengan menggunakan iOS Programming, yang diharapkan bisa di akses melalui iPhone dan iPad yang bisa di download melalui iTunes demi meningkatkan peran media dalam perguruan tinggi supaya jauh lebih baik dan tentunya bermanfaat[9].

5. Penelitian ini dilakukan oleh Untung Rahardja, Henderi dan Arwan dari Perguruan Tinggi Raharja tahun 2012 yang berjudul "Perancangan Aplikasi iLearning Journal Information Pada Perguruan Tinggi”. Penelitian ini membahas perihal kewajiban menghasilkan sebuah paper jurnal ilmiah yang merupakan ketentuan yang di ciptakan dalam rangka untuk meningkatkan kualitas dan mutu pendidikan di Indonesia. Pada sistem pembelajaran iLearning proses belajar mengajar membutuhkan aplikasi-aplikasi yang terdapat di iPad. Berdasarkan hasil survey dan penelitian yang telah di laksanakan, mendapatkan tidak semua aplikasi pendukung tersebut terdapat di iPad, terutama aplikasi yang dapat mendukung dalam proses pembuatan dan publikasi jurnal, maka dari pada itu diciptakan suatu aplikasi pendukung "iJOIN" (iLearning Journal information), sebagai salah satu aplikasi yang mendukung sistem pembelajaran iLearning[10]. 
6. Penelitian ini dilakukan oleh Untung Rahardja, Ary Budi Warsito dan Dini Nurul Suvianti dari Perguruan Tinggi Raharja tahun 2012 yang berjudul "Penerapan Aplikasi iDINI sebagai Media Penyimpanan Materi Perkuliahan iLearning Pada Perguruan Tinggi”. Penelitian ini membahas perihal media pembelajaran dengan menggunakan iBooks yang dalam iBooks kita bisa mendapatkan kemudahan membaca karena di dalamnya anda dapat mengkategorikan file yang berupa pdf atau dokumen lainya. iBooks adalah aplikasi yang sangat baik dan terbaik bagi anda yang suka membaca banyak buku, karena dengan iBooks anda bisa membaca ribuan buku bacaan anda tanpa harus membawa buku yang tebal dan banyak, dan ini lah aplikasi yang selalu di tampilkan apps store pada saat kita pertama kali membuat account apple id. Sebagian besar sistem pelayanan masih dilakukan secara face to face antara mahasiswa yang memerlukan pelayanan dan petugas pelaksana yang memberikan pelayanan[11].

7. Menurut (Priyo Puji Nugroho:2012) Single Sign On adalah adalah sebuah mekanisme yang membuat user hanya perlu mengingat satu username dan password yang autentik untuk membuka beberapa layanan sekaligus. Dari dua pengertian tersebut yang dapat saya ambil bahwa single sign on system merupakan suatu mekanisme autentikasi untuk dapat mengakses keseluruhan sumber daya seperti beberapa situs atau layanan lainnya hanya dengan satu kali login saja.

8. Penelitian yang dilakukan oleh Jumar Slamet dengan judul "Otak-Atik Google Form Guna Pembuatan Kuesioner Kepuasan Pemustaka". Penelitian ini membahas pemanfaatan Google form untuk kuesioner sebagai pengukuran tingkat kepuasan pemustaka terhadap layanan perpustakaan. Kuesioner kepuasan pemustaka yang dibuat dan di share melalui Google form dapat diakui sebagai langkah positif guna pendukung kebutuhan informasi dari pemustaka. [7]

Dari delapan Literature review yang ada, telah banyak penelitian mengenai metode penilaian secara Online.

\section{PEMECAHAN MASALAH}

Berdasarkan observasi, sistem penilaian nya yang dilakukan pada Perguruan Tinggi Raharja sudah cukup baik, namun sejalan dengan kemajuan dan perkembangan teknologi serta pengembangan kebutuhan Pribadi Raharja pada umumnya atas informasi mengenai segala bentuk pemberitahuan dan pengumuman secara umum maupun khusus, kedisiplinan dan layanan kepada mahasiswa/i, maka sistem ini memerlukan sistem yang benar-benar handal dan dapat berfungsi semaksimal mungkin untuk memberikan informasi serta memenuhi kebutuhan tersebut.

Oleh karena itu berdasarkan analisa dari segi kekurangan serta kebutuhan saat ini, kebutuhan terhadap sistem hendaknya dapat melihat dan menambahkan data-data serta informasi yang dibutuhkan oleh mahasiswa/i demi mengoptimalkan informasi di Perguruan Tinggi Raharja sehingga dapat memaksimalkan berbagai bentuk pelayanan kepada mahasiswa/i baik informasi yang dibutuhkan maupun keseluruhan. Selain itu dapat memberikan informasi yang akurat dan up to date sehingga informasi yang didapatkan Relevan sesuai dengan kebutuhan mahasiswa/i.

Segala hal pada dasarnya untuk mengatasi berbagai masalah diatas, maka diperlukan proses yang cepat dan efisien dalam mengakses seluruh data yang banyak dan tidak teratur dalam media penyimpanan yang berupa sebuah aplikasi, terutama PEN+ (Penilaian Plus) yaitu Penilaian Online Plus terlebih untuk suatu sistem informasi yang akurat. 
Berikut langkah-langkah pemecahan masalah :

1). Langkah pertama Akses Halaman SiS+

Anda bisa membuka halaman $\mathrm{SiS}+$ dengan mengunjungiwebsite berikut http://sisplus.raharja.ac.id

\section{2). Login $\mathrm{SiS}+$}

Langkah kedua Setelah berhasil masuk halaman website SiS+ berikutnya lakukan login dgn menggunakan email Rinfo dan Pastikan Device anda sudah login terlebih dahulu.

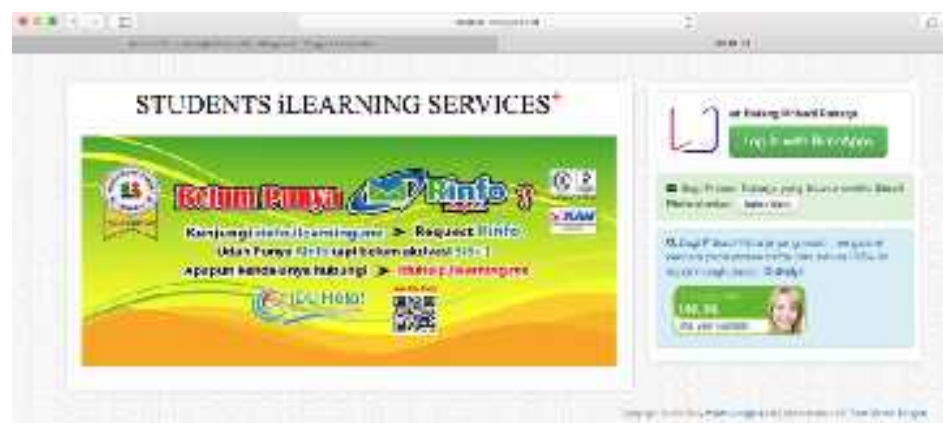

\section{Gambar 2 . Tampilan SIS+}

*Note: Jika belum mempunyai email Rinfo, anda bisa daftar langsung pada link berikut: http://eco.ilearning.me dan jika belum Register SiS+, anda bisa daftar langsung DISINI.

\section{3). Langkah ketiga ketika login berhasil Anda bisa langsung klik Penplus}

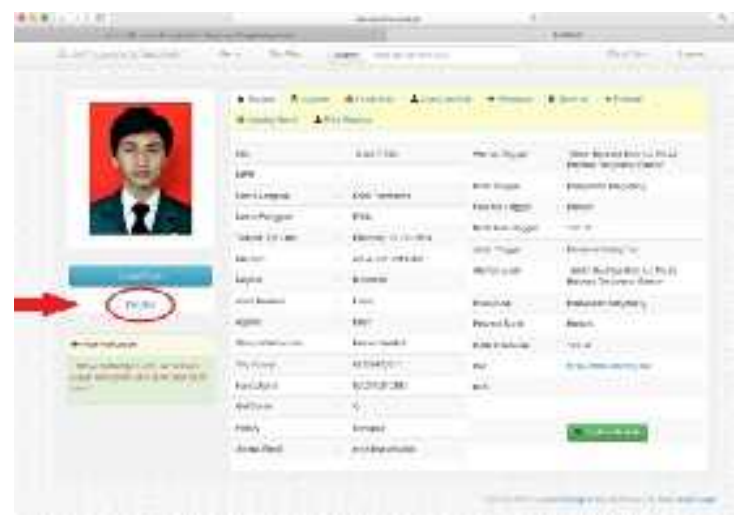

Gambar 3 . Tampilan biodata dosen pada SIS+ 
4). Langkah keempat ini adalah tampilan Viewboard Pen+ untuk Dosen

Berikut adalah tampilan Viewboard Dosen pada Sistem Pen+, Kemudian klik salah satu kelas yang ingin di input Nilainya seperti gambar berikut:

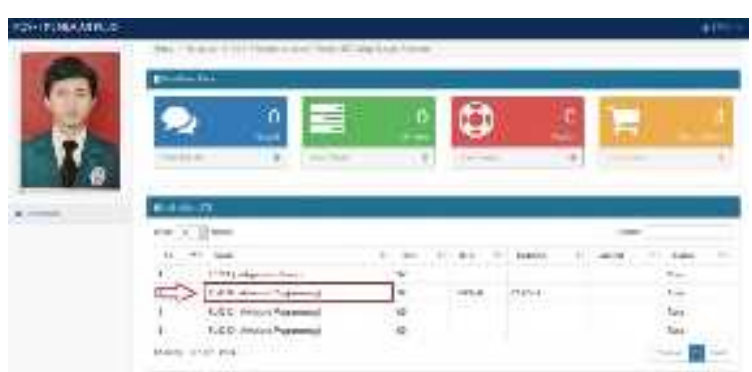

Gambar 4 . Tampilan VB dosen di sistem Pen+

5). Langkah kelima Klik Buttom Nilai untuk menginput Hasil Nilai tersebut.

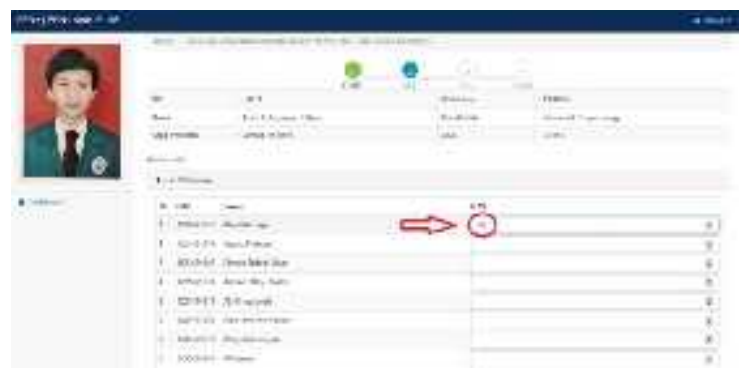

Gambar 5 . Tampilan untuk dosen input nilai

6). Langkah keenam input Nilai satu persatu berdasarkan Hasil Mahasiswa/i.

Jika sudah semua Nilai terinput kemudian Klik Submit.

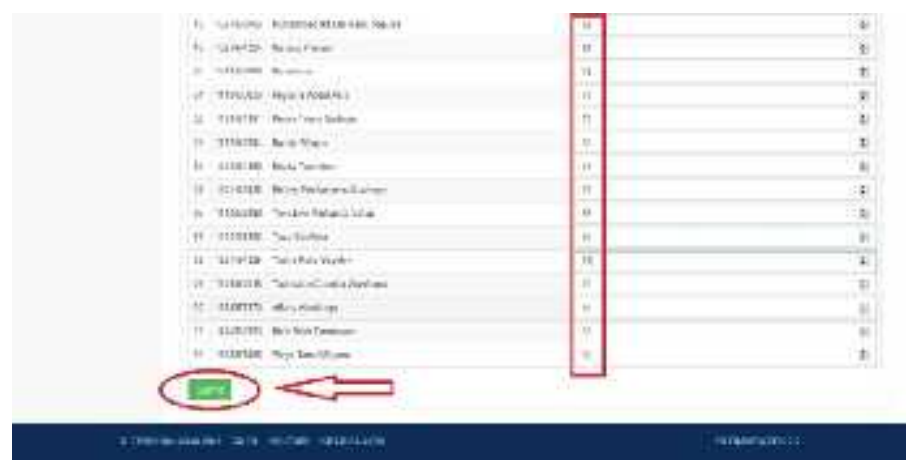

Gambar 6. Tampilan nilai yang sudah di isi oleh Dosen 
7). Langkah ketujuh muncul sebuah Pop up seperti kata-kata berikut "do you really submit this value?" Klik Oke.

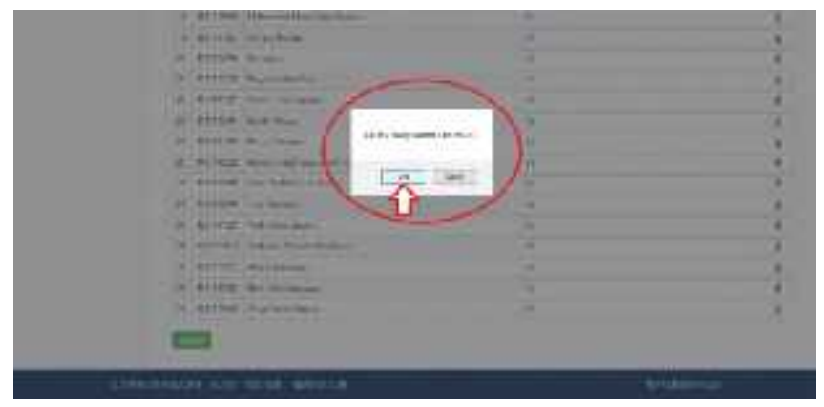

Gambar 7 . Tampilan Dosen sudah selesai mengisi nilai

8). Langkah kedelapan semua Nilai tersubmit dan Otomatis menampilkan Grade.

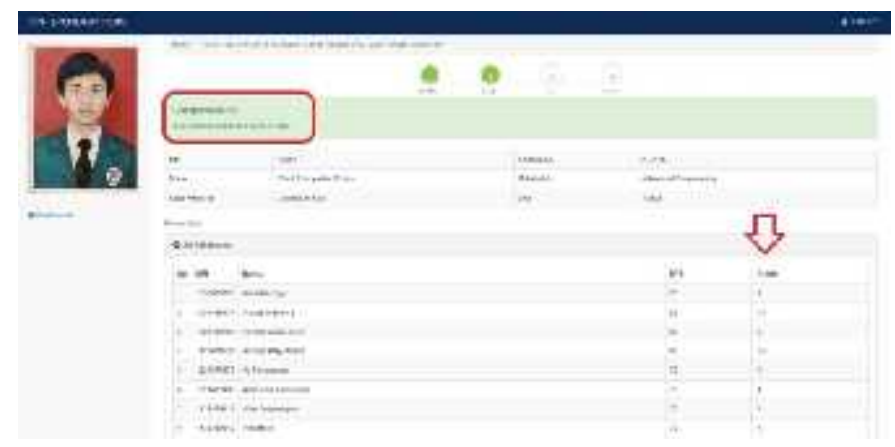

Gambar 8 . Tampilan Dosen selesai mengupdate nilai

\section{Mind Mapping}

Mind mapping adalah cara paling efektif dan efesien untuk memasukan, menyimpan dan mengeluarkan data baru atau ke otak. Sistem ini bekerja sesuai cara kerja alami, sehingga dapat mengoptimalkan seluruh potensi dan kapasitas otak manusia ([Caroline Edwart, 2009:64])

Dilihat dari segi waktu, mind mapping dapat memberikan efisiensi pengguna dalam mempelajari informasi. Hal ini disebabkan karena meotode ini dapat memberikan gambaran secara luas dan menyeluruh dengan waktu yang lebih singkat.

Pada metode penggunaan Mind Mapping ini dapat menghasilkan penjelasan mengenai Single Sign On (SSO) pada PEN+. Tujuan dari SSO untuk dapat memberikan keamanan dan kemudahan pengguna dalam mengakses PEN+ Kekurangan SSO ini yaitu masih terdapat pengguna yang belum memiliki akun Rinfo. Kelebihan PEN+ yaitu memudahkan pengguna dalam melakukan login tanpa perlu memasuki username dan juga password. 

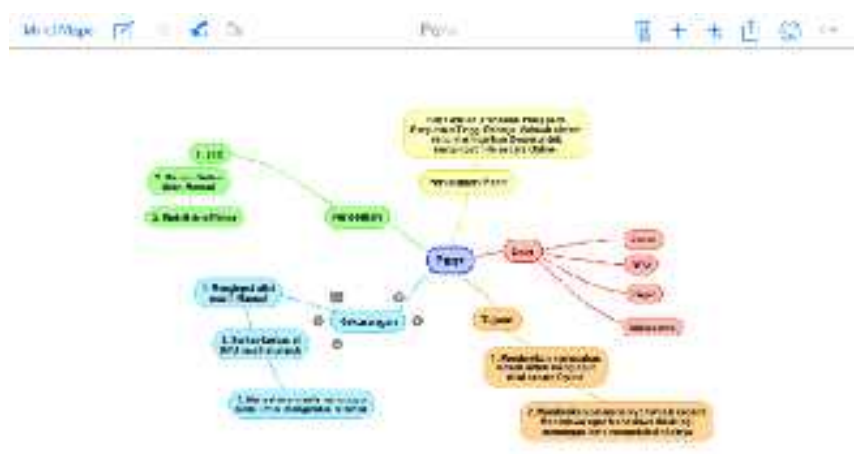

\section{Gambar 9. Mind Map PEN+}

\section{Flowchart Rancangan Aplikasi}

Flowchart adalah bagan-bagan yang mempunyai arus yang menggambarkan langkah-langkah penyelesaian masalah.Flowchart merupakan cara penyajian dari suatu algoritma[3]. Flowchart ini menunjukan setiap langkah program atau prosedur dalam urutan yang tepat saat terjadi. Berikut ini flowchart mengenai Single Sign On pada PEN+ :

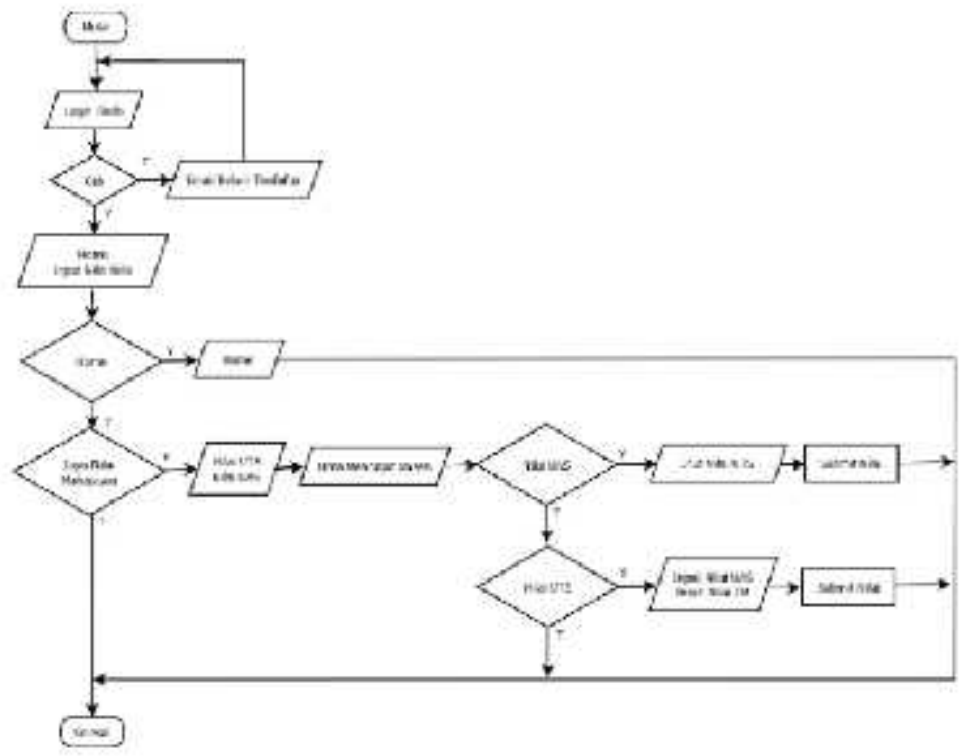

Gambar 10. Flowchart Sistem Untuk Input Nilai Oleh Dosen 


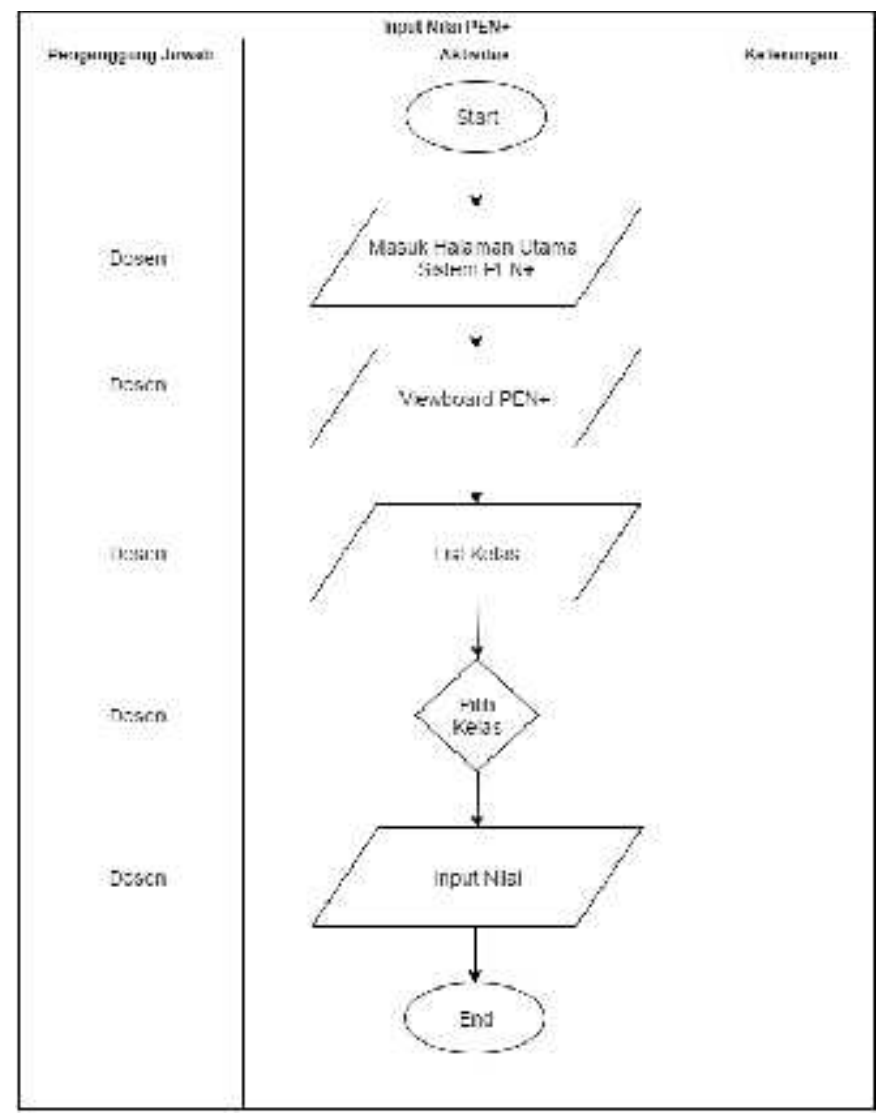

Gambar 11 . Activity Diagram Input Nilai PEN+

Kelebihan sistem PEN+ sangat berbeda dengan sistem penilaian yang lain, karena sistem ini mempunyai ciri khas dari sistem penilaian yang lain dan sistem ini sangat bermanfaat dan sangat penting untuk digunakan oleh Dosen yang digunakan dalam penginputan nilai .

Sedangkan dalam perancangan aplikasi menggunakan aplikasi blueprint. Blueprint merupakan suatu aplikasi iPad yang digunakan untuk membuat perancangan suatu aplikasi sehingga tampak seperti aplikasi yang sudah jadi. Berikut merupakan tahapan proses pembuatan aplikasi.

Berikut langkah-langkah pemecahan masalah :

\section{KONSEP PENILAIAN}

Penilaian pembelajaran merupakan salah satu bagian penting dalam penyelenggaraan pendidikan yang bertujuan untuk mengetahui seberapa besar kompetensi yang telah dicapai peserta didik selama dan setelah proses pembelajaran yang telah diselenggarakan. Tujuan lain penilaian dalam pembelajaran adalah untuk mengevaluasi pembelajaran yang telah dilaksanakan berdasarkan penilaian yang telah dilakukan, yaitu apa yang harus diperbaiki dan apa yang harus ditingkatkan. Penilaian dalam pembelajaran dilakukan setelah melakukan pengukuran yang berkenaan dengan kompetensi apa saja yang akan dinilai. Setelah dilakukan penilaian, langkah selanjutnya adalah melakukan evaluasi pembelajaran. Jadi urutannya adalah: pengukuran, penilaian, dan evaluasi pembelajaran. 


\section{a. Pengukuran}

Pengukuran (Djemari Mardapi, 2012) pada dasarnya merupakan kegiatan penentuan angka bagi suatu objek secara sistematik. Penentuan angka ini merupakan usaha untuk menggambarkan karakteristik suatu objek. Jadi, pengukuran adalah usaha yang dilakukan untuk memperoleh informasi yang menggambarkan karakteristik suatu objek. Informasi yang diperoleh berupa angka berdasarkan kriteria yang telah ditetapkan sebelumnya

\section{b. Penilaian}

Penilaian adalah prosedur yang sistematis untuk mengumpulkan informasi yang dapat digunakan untuk membuat kesimpulan tentang karakteristik orang atau objek (Reynold, et al, 2009). Selanjutnya, Djemari Mardapi (2012) menyatakan bahwa penilaian mencakup semua cara yang digunakan untuk mengumpulkan data tentang individu. Untuk menilai prestasi peserta didik, peserta didik mengerjakan tugas-tugas, mengikuti ujian tengah semester, dan ujian akhir semester. Semua data diolah menjadi informasi tentang individu.

\section{c. Evaluasi}

Pengertian evaluasi menurut Djemari Mardapi (2008) merupakan salah satu kegiatan dalam meningkatkan kualitas, kinerja, atau produktivitas suatu lembaga dalam melaksanakan programnya. Fokus evaluasi adalah individu, yaitu prestasi belajar yang dicapai kelompok atau kelas. Melalui evaluasi akan diperoleh informasi tentang apa yang telah dicapai dan mana yang belum, dan selanjutnya informasi ini digunakan untuk perbaikan suatu program (Djemari Mardapi, 2008).

\section{IMPLEMENTASI}

Tampilan PEN+ (Penilaian Plus) memiliki berbagai viewboard yang dapat digunakan oleh Dosen yang terdiri dari :

\section{a. Tampilan Utama Viewboard Dosen}

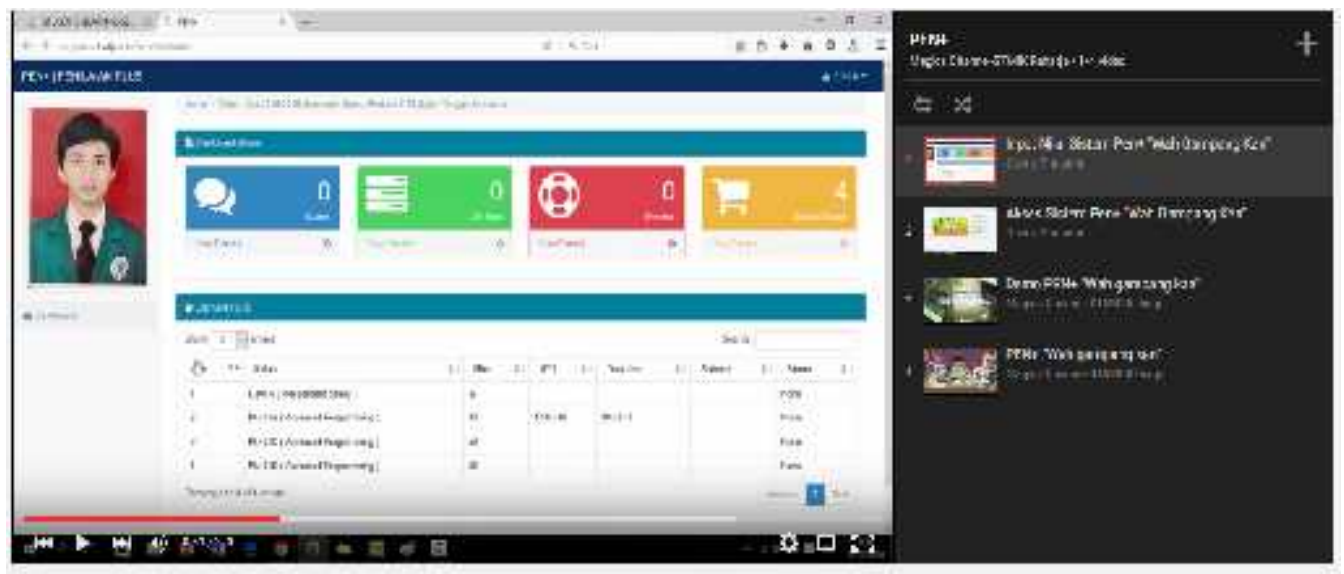

Sumber : Viewboard Dosen (sisplus.raharja.ac.id)

Gambar 11. TampilanViewboard Dosen 
Pada gambar diatas adalah tampilan Viewboard untuk Dosen, Langkah awal untuk masuk pada Viewboard adalah yang pertama Login menggunakan SIS+ dan Dosen melakukan submit pada Viewboard Dosen sesuai dengan matakuliah dan kode kelasnya yang diampuh.

\section{b. Tampilan Respondes Kusioner PEN+}

Pada gambar dibawah ini adalah sebuah form implementasi yang dilakukan oleh sistem PEN+ dengan menggunakan kuisioner intuk diisi oleh Mahasiswa, Form kuisioner ini berfungsi untuk Mahasiswa yang ingin mengisi form tersebut dan dijadikan Assignment kepada dosennya. Dan berikut dibawah ini adalah Form kuisioner PEN+ :

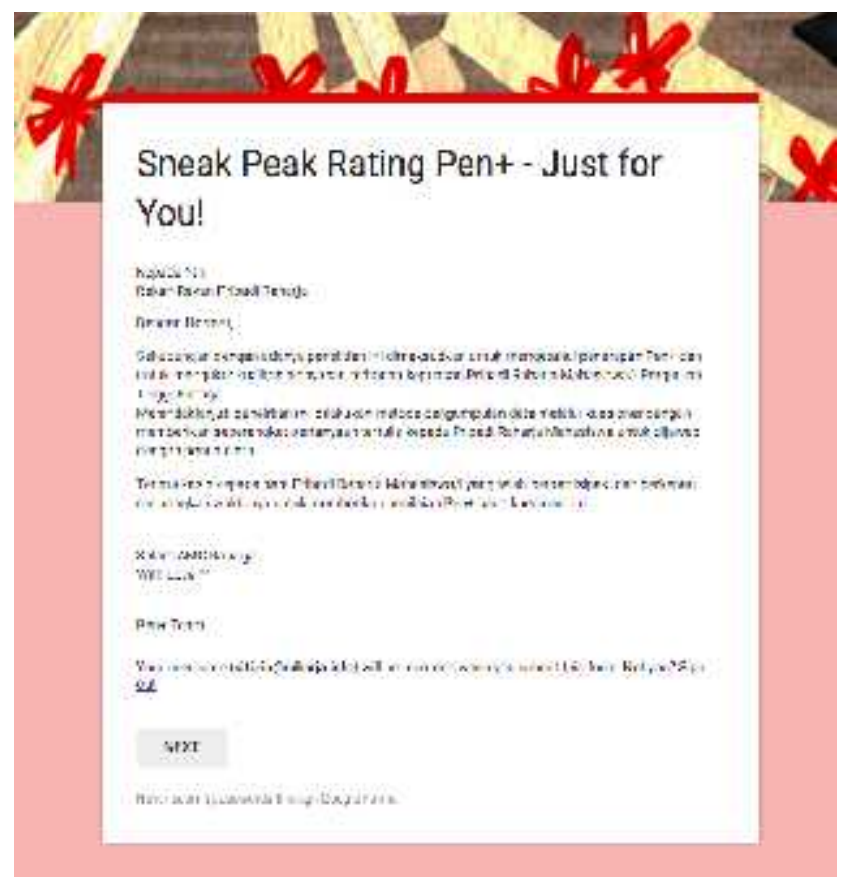

Gambar 12. Tampilan Awal Responded Kuisioner PEN+

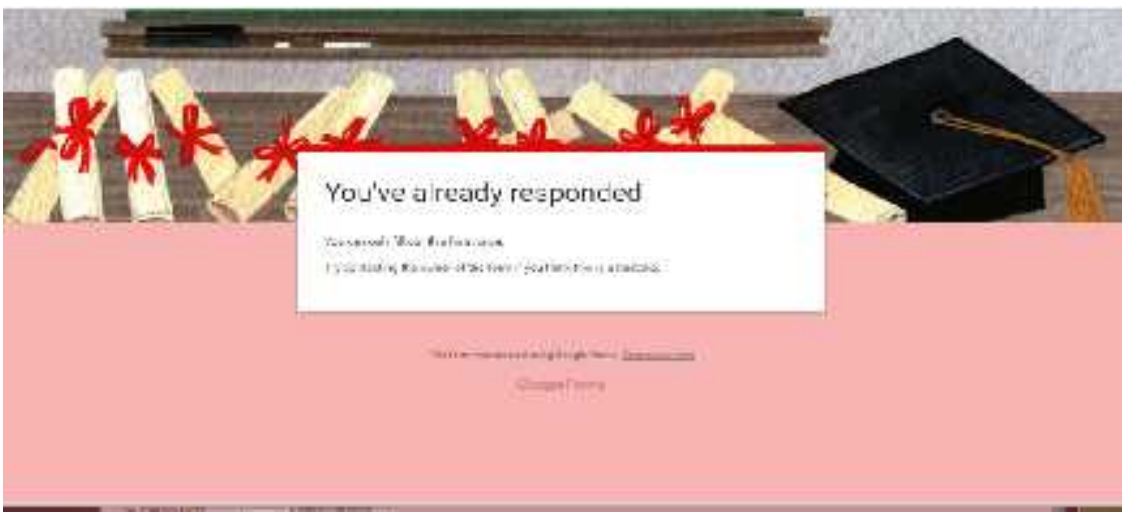

Gambar 13. Tampilan Akhir Responded Kuisioner Mahasiswa (Jika sudah mengisi Kuisioner) 
Pada tampilan ini ada tahap Uji Coba PEN+ dan dilakukannya Implementasi . Dari 1.581 Mahasiswa PEN+ mengirimkan kuisioner oleh Pribadi Raharja dengan sesuai target, PEN+ mendapatkan 645 Mahasiswa yang telah merespon dan mengisi form kuisioner PEN+. Bisa dilihat pada gambar dibawah ini :

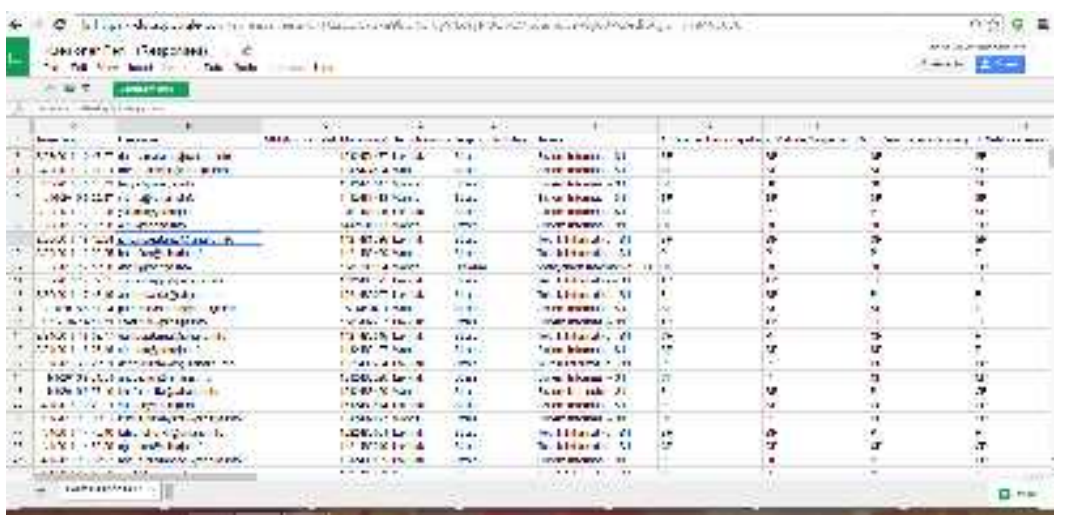

Gambar 14. Hasil Kuisioner PEN+ Response

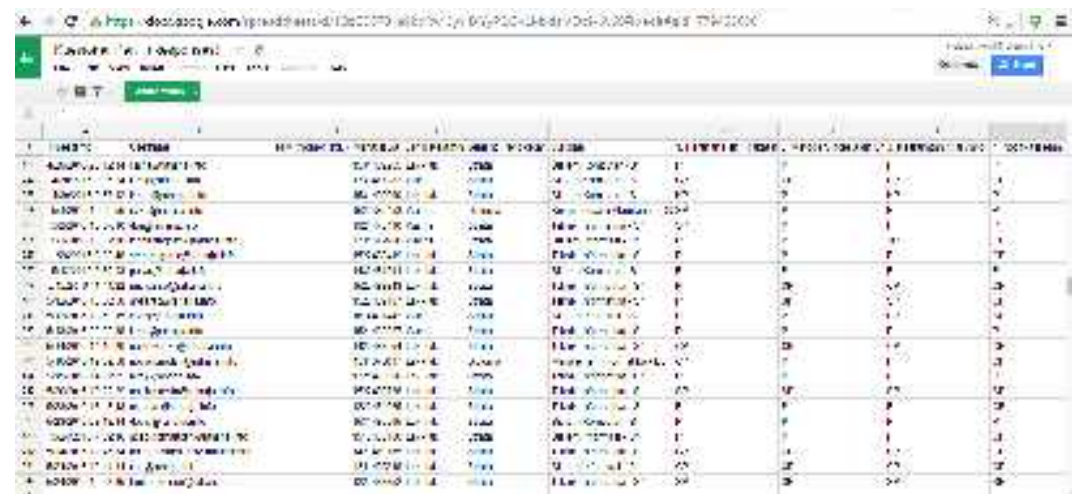

Gambar 15. Hasil Kuisioner PEN+ Response (Akhir)

Dari jumlah 1.851 Mahasiswa ada 645 Mahasiswa yang mengisi kuisioner PEN+ dan sudah mencapai sebuah target yang telah mengisi kuisioner PEN+ ini dan dijadilkan sebuah diagram kuisioner PEN+ Mahasiswa. 


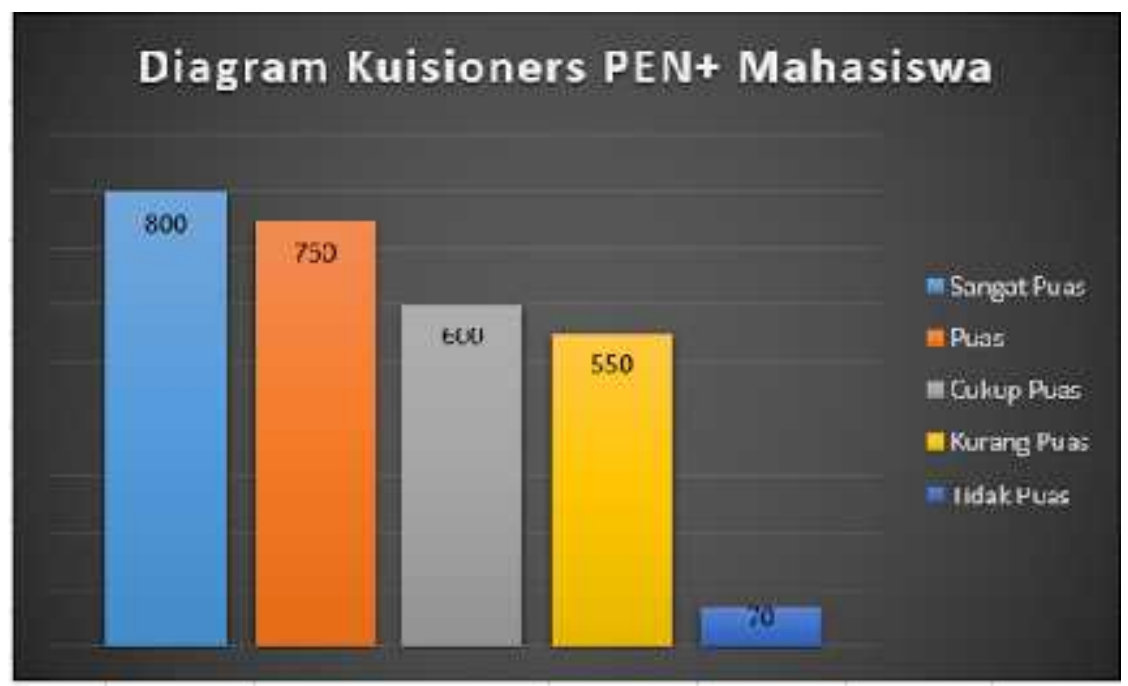

Gambar 16. Diagram Kuisioner PEN+

Pada gambar diatas adalah tampilan diagram kuisioner PEN+ Mahasiswa yang telah mengisi kuisioner dan hasil ini telah tercatat dari Kepuasan Mahasiswa.

\section{KESIMPULAN}

Dari semua pembahasan diatas dapat disimpulkan bahwa sistem penilaian Online ini sangatlah penting untuk dikembangkan di Perguruan Tinggi Raharja dan dengan adanya sistem PEN+ ini dapat membantu dan meringankan Dosen dalam penginputan nilai dan Dosen tidak lagi terlambat untuk melakukan penginputan nilainya karena waktu yang ditentukan oleh Dosen yaitu H+3 setelah ujian berlangsung. Sistem PEN+ ini telah diimplementasikan di Perguruan Tinggi Raharja untuk menghasilkan Penilaian yang terbaik. Saat ini seluruh Perguruan Tinggi memiliki tempat khusus untuk menyimpan seluruh kegiatan maupun dokumentasi yang telah di selenggarakan oleh kampus tersebut, begitu pula dengan Perguruan Tinggi Raharja yang telah memiliki PEN+ (Penilaian Plus) untuk memperoleh Penilaian yang masih belum maksimal, sesuai dengan penjabaran pada permasalahan diatas terdapat permasalahan yang ada yaitu diantaranya masih bersifat manual, Dan memberikan kepuasan Mahasiswa dengan adanya sistem Pen+ ini, Mahasiswa tidak lagi meunggu dengan lama mengertahui nilainya pada SIS+. Nilai di input secara Online dan bisa digunakan dimana saja secara online terhadap Dosen, Mahasiswa bisa melihat nilai mereka sendiri hanya dengan melakukan sisplus.raharja.ac.id, lalu search dengan kata kunci Pen+ (Penialaian plus) login dengan menggunakan Rinfo Mahasiswa atau Dosen sudah bisa mengakses Pen+.

\section{DAFTAR PUSTAKA}

[1] Erlita Rasdiana pada tahun 2013 dengan judul "Analisa pengembangan sistem System Information Student (SIS) pada Perguruan Tinggi Raharja

[2] Susy Kusuma Wardani pada tahun 2013 dengan judul "Sistem Informasi Pengolahan Data Nilai siswa berbasis Web pada Sekolah Menengah Atas (SMA) Muhammadiyah pacitan”.

[3] Rahmawati pada tahun 2012 yang berjudul "Analisa Penerapan Sistem Informasi Akademik (SIAKAD) Online di Universitas Sultan Ageng Tirtayasa" 
[4] Untung Rahardja, Muhamad Yusup dan Eva Rosyifa dari Perguruan Tinggi Raharja tahun 2012 yang berjudul "Perancangan Aplikasi iLearning Majalah Online Dengan Menggunakan iOS Programming Pada Perguruan Tinggi"

[5] Untung Rahardja, Henderi dan Arwan dari Perguruan Tinggi Raharja tahun 2012 yang berjudul "Perancangan Aplikasi iLearning Journal Information Pada Perguruan Tinggi"

[6] Ary Budi Warsito dan Dini Nurul Suvianti dari Perguruan Tinggi Raharja tahun 2012 yang berjudul "Penerapan Aplikasi iDINI sebagai Media Penyimpanan Materi Perkuliahan iLearning Pada Perguruan Tinggi"

[7] Kelly D. LEWIS, James E. LEWIS, Ph.D “Web Single Sign-On Authentication using SAML ". IJCSI International Journal of Computer Science Issues, Vol. 2, 2009Slamet, Jumar. "Otak-Atik

[8] Google Form Guna Pembuatan Kuesioner Kepuasan Pemustaka". Info persadha 14.1 (2016):21-35. 